\title{
Mobile-Based Learning to Increase The Motivation of Learning Students of State Vocational School 2 Gorontalo
}

\author{
${ }^{1}$ Syaifuddin, ${ }^{2}$ Hamka Witri Kamase \\ ${ }^{1,2}$ STMIK ICHSAN GORONTALO, Indonesia \\ Isyaifuddinlily@gmail.com; ${ }^{2}$ hamkawitri@gmail.com;
}

\begin{tabular}{l}
\hline \hline Article Info \\
\hline Article history: \\
Received, 13/11/2021 \\
Revised, 19/11/2021 \\
Accepted, 22/11/2021 \\
\\
\hline Kata Kunci: \\
Mobile Learning \\
Android \\
HTML \\
PHP \\
\end{tabular}

\section{Keywords:}

Mobile Learning

Android

HTML

PHP

\begin{abstract}
ABSTRAK
Sistem Pembelajaran di Indonesia dilakukan dengan sistem tatap muka, kegiatan belajar mengajar dilakukan di sekolah dalam satu ruangan. Meluasnya pandemi virus covid 19 membuat kementerian Pendidikan dan kebudayaan mengambil kebijakan untuk melakukan kegiatan sekolah online dengan maksud mencegah terjadinya penularan virus penyakit. Pembelajaran online tidak semuanya harus dilakukan dengan menggunakan Zoom atau aplikasi sejenisnya, diperlukan juga aplikasi yang dapat dikelola oleh sekolah dan menyeragamkan penggunaannya sehingga guru mudah melakukan pengisian materi dan tugasnya. Sistem pembelajaran yang dilakukan di SMK negeri 2 Gorontalo dinilai kurang efektif sehingga berpengaruh pada hasil belajar. Aplikasi yang dibuat adalah aplikasi yang dapat membantu proses belajar dan mengajar di SMK negeri 2 Gorontalo. Penggunaan media pembelajaran diharapkan dapat membantu memudahkan penyerapan materi serta penyampaian isi pelajaran sehingga menambah motivasi siswa untuk mempelajari dan memahaminya dimana saja dan kapan pun. Metode yang digunakan adalah metode Research and Development. sebagai metode penelitian yang digunakan untuk menghasilkan produk tertentu dan menguji keefektifan produk tersebut dimana objek penelitian dalam penelitian adalah Siswa pada SMK Negeri 2 Gorontalo. Tujuan penelitian adalah untuk membantu meningkatkan motivasi belajar siswa dimasa pandemi.$$
\text { ABSTRACT }
$$

Learning System in Indonesia is carried out with a face-to-face system, teaching and learning activities are carried out in schools in one room. The widespread pandemic of the covid 19 virus made the Ministry of Education and Culture take a policy to conduct online school activities to prevent the transmission of the disease virus. Online learning does not all have to be done using Zoom or similar applications. It is also necessary that applications that schools can manage and uniformize their use so that teachers can quickly fill out materials and tasks. The learning system carried out in SMK Negeri 2 Gorontalo is considered less effective, affecting learning outcomes. The application created is an application that can help the learning and teaching process in SMK Negeri 2 Gorontalo. Learning media is expected to help facilitate the absorption of the material and the delivery of lesson content to increase students' motivation to learn and understand it anywhere and anytime. The method used is the Research and Development method. As a research method used to produce a particular product and test the effectiveness of the product where the object of research in the study is a Student at SmK Negeri 2 Gorontalo. The purpose of the study is to help increase students' learning motivation in times of pandemics.
\end{abstract}

This is an open-access article under the CC BY-SA license.

\footnotetext{
Penulis Korespondensi:

Syaifuddin,

Program Studi Sistem Informasi,

STMIK Ichsan Gorontalo,

Email: syaifuddinlily@gmail.com
}

\section{PENDAHULUAN}

Sistem Pembelajaran di Indonesia dilakukan dengan sistem tatap muka, kegiatan belajar mengajar dilakukan di sekolah dalam satu ruangan. [1] Siswa belajar menurut buku panduan dari guru. Meluasnya pandemi virus covid 19 membuat kementerian Pendidikan dan kebudayaan mengambil kebijakan untuk melakukan kegiatan sekolah online dengan maksud mencegah terjadinya penularan virus penyakit. [2] Dalam rangka mencegah meluasnya penularan Covid-19 pada warga sekolah khususnya dan masyarakat luas pada 
umumya, Kementerian Pendidikan dan Kebudayaan (Kemendikbud) menerbitkan beberapa surat edaran terkait pencegahan dan penanganan Covid-19. [3]

Saat ini yang sedang berkembang adalah sistem pembelajaran E-Learning. [4] [5] E-Learning merupakan media pembelajaran yang digunakan untuk sarana belajar siswa agar mudah mengakses materi dimanapun dan kapanpun sehingga pembelajaran bisa efektif dan efisien. [6] Materi pembelajaran dapat divisualisasikan dalam berbagai format dan bentuk teknologi informasi saat ini yang sedang berkembang adalah sistem pembelajaran Mobile Learning. [7] . Pembelajaran online tidak semuanya harus dilakukan dengan menggunakan Zoom atau aplikasi sejenisnya, diperlukan juga aplikasi yang dapat dikelola oleh sekolah dan menyeragamkan penggunaannya sehingga guru mudah melakukan pengisian materi dan tugasnya. [8]

Sistem pembelajaran yang dilakukan di SMK negeri 2 Gorontalo dinilai kurang efektif sehingga berpengaruh pada hasil belajar. [9] Aplikasi yang dibuat adalah aplikasi yang dapat membantu proses belajar dan mengajar di SMK negeri 2 Gorontalo. Penggunaan media pembelajaran diharapkan dapat membantu memudahkan penyerapan materi serta penyampaian isi pelajaran sehingga menambah motivasi siswa untuk mempelajari dan memahaminya dimana saja dan kapan pun. [10]

\section{METODE PENELITIAN}

Penelitian menggunakan metode Research and Development atau yang dikenal dengan metode Penelitian dan Pengembangan. [11] Metode didefinisikan sebagai metode penelitian yang digunakan untuk menghasilkan produk tertentu dan menguji keefektifan produk tersebut dimana objek penelitian dalam penelitian adalah Siswa pada SMK Negeri 2 Gorontalo. [12]

Menurut [13], langkah-langkah penelitian dan pengembangan dapat disederhanakan menjadi lima langkah utama yaitu:

1. Langkah awal adalah melakukan Observasi dan wawancara tahap awal ke lokasi penelitian untuk mengetahui melakukan analisis kebutuhan produk yang akan dikembangkan, Peneliti melakukan wawancara dengan kepala sekolah dan beberapa guru bagian TIK di SMK Negeri 2 Gorontalo dengan maksud agar lebih mudah untuk mensosialisasikan aplikasi pada semua guru.

2. Mengembangkan produk awal, Aplikasi didesain tidak langsung diterapkan ke semua kelas melainkan dicoba oleh guru TIK dan dikoreksi sesuai dengan kebutuhan Guru dan siswa.

3. Vaidasi ahli dan revisi, Di tahap ini perbaikan demi perbaikan dilakukan untuk mendapatkan aplikasi yang diharapkan

4. Uji coba lapangan skala kecil dan revisi Program, pada tahap ini Aplikasi yang telah melalui tahap validasi maka akan dicoba ke dua kelas yang dipilih selama satu bulan.

5. Uji coba lapangan skala besardan program akhir, Ini adalah tahap akhir dimana Aplikasi Mobile learning di terapkan pada SMK negeri 2 Gorontalo.

\section{Metode Pengumpulan Data}

Teknik pengumpulan data dilakukan dengan cara: [14]

1. Observasi, teknik ini dilakukan dengan melakukan pengamatan langsung di tempat penelitian, yaitu pada SMK Negeri 2 Gorontalo.

2. Interview, pengumpulan data dengan cara tatap muka dan tanya jawab langsung dengan sumber data yaitu Kepala Sekolah SMK Negeri 2 Gorontalo.

\section{HASIL DAN ANALISIS}

Analisis

Sistem Yang Di rencanakan

Rancangan sistem aplikasi mobile learning yang akan diterapkan di SMK Negeri 2 Gorontalo. Terdapat 3 aktor yang menggunakan sistem yaitu Admin, Guru dan siswa. Ketiga aktor mengakses sesuai dengan hak akses masing - masing. Pemodelannya menggunakan UML [15] 


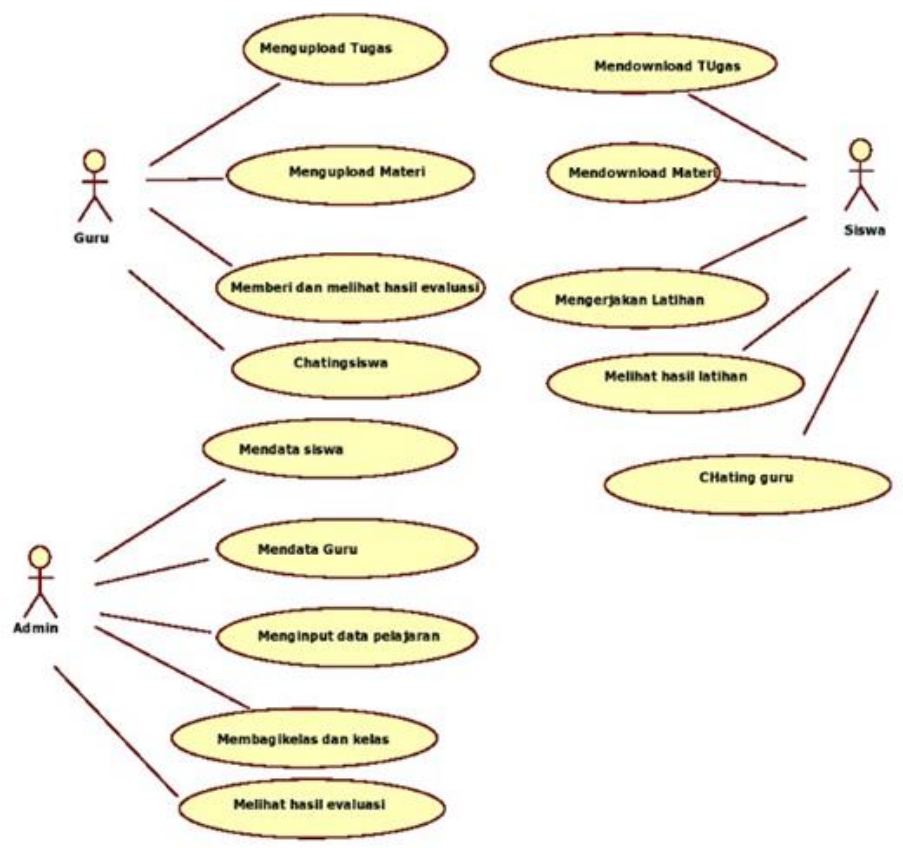

Gambar 1. Sistem yang direncanakan

\section{Halaman Aplikasi dan penggunaannya}

1. Tampilan Halaman beranda

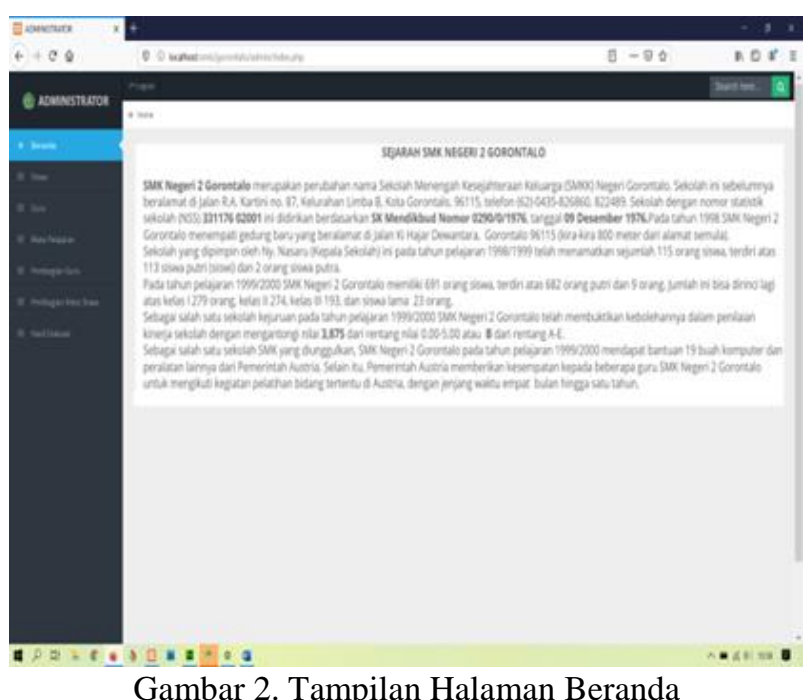

Tampilan Halaman utama dari Mobile-Based Learning di SMK Negeri 2 Gorontalo. Tampilan awal yang didapat oleh Admin dan Guru, Pada tampilan terdapat menu yang bisa diakses berdasarkan hak akses masing - masing. Hak akses Admin memungkinkan Admin untuk menginput data guru, data mata pelajaran, input pembagian kelas, Input Data Siswa. 


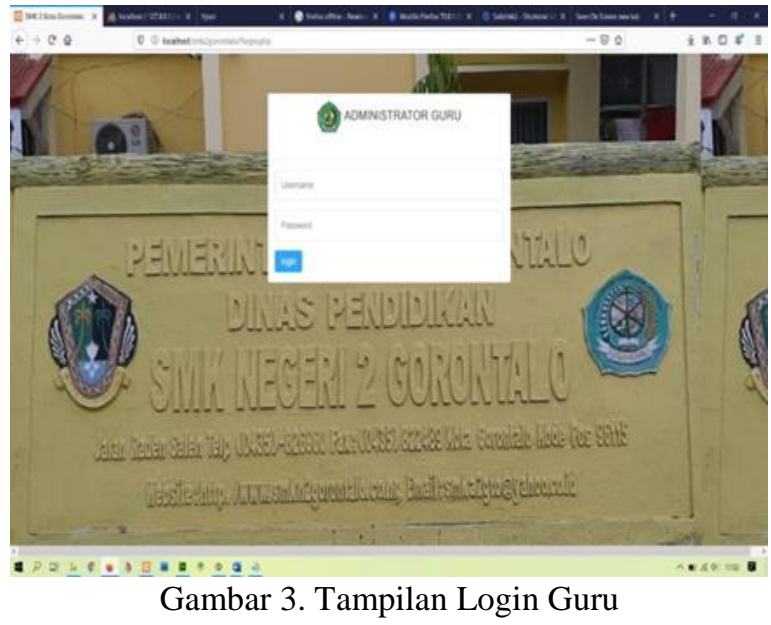

Tampilan Gambar 3 diatas merupakan halaman Login guru. Hak akses guru dibedakan dengan admin. Aktor guru akan masuk ke halaman beranda Guru jika sudah memasukkan username dan Password.

3. Halaman beranda Admin Guru

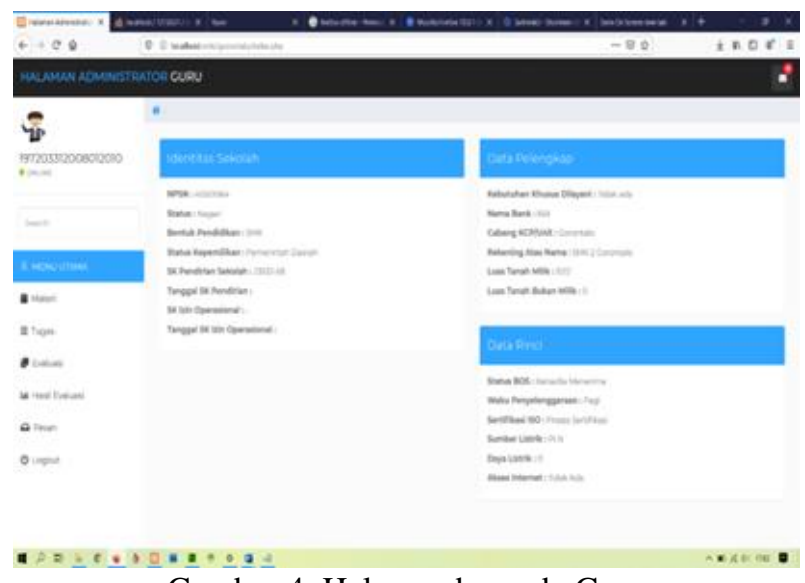

Gambar 4. Halaman beranda Guru

Tampilan Gambar 4 adalah tampilan halaman beranda Guru, Setelah memasukkan username dan Password, Guru diizinkan untuk mengakses ke dalam sistem mobile learning. Halaman beranda Guru terdapat menu-menu yang memungkinkan guru untuk menginput Daftar Materi, Materi, Daftar Tugas, dan melihat hasil evaluasi ujian yang dilakukan.

4. Halaman Tampilan Input Materi

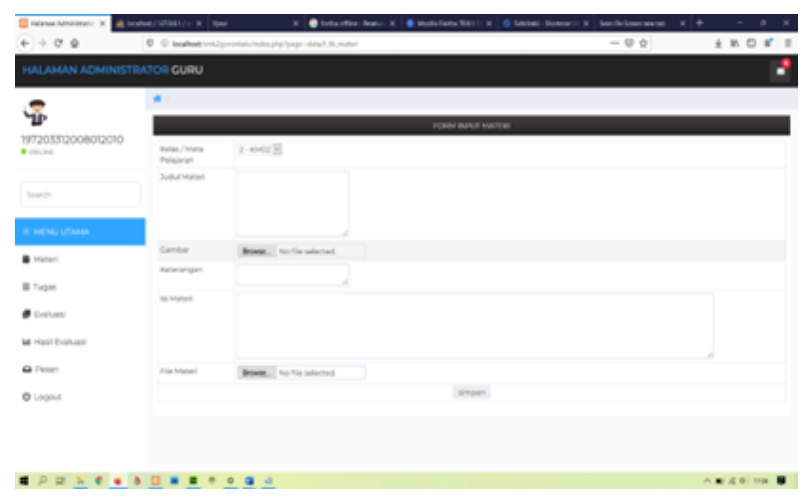

Gambar 5. Tampilan input Materi

Gambar 5. Merupakan tampilan input materi, Terdapat beberapa pilihan mengisi sesuai dengan pembagian kelas yang dilakukan oleh Admin.

5. Halaman Tampilan Input Tugas 


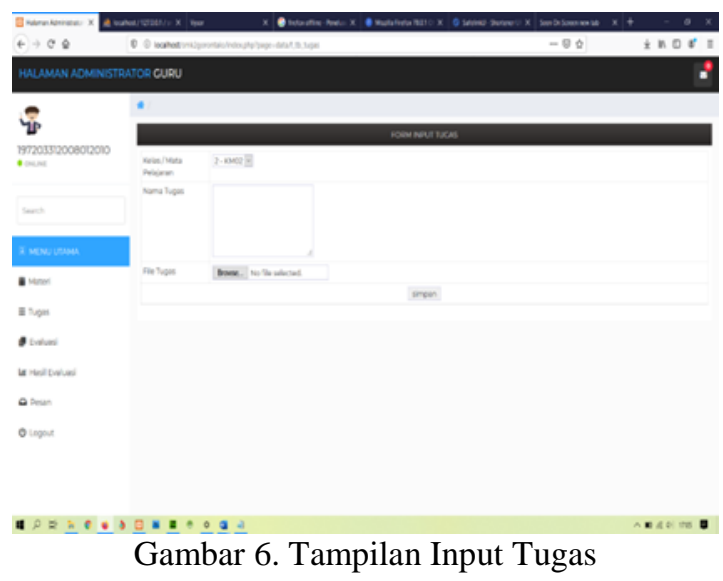

Tampilan Gambar 6. Adalah tampilan Input tugas, setiap guru menginput tugas masing - masing ke dalam sistem sesuai dengan kelas yang diajarinya.

6. Tampilan Hasil Evaluasi

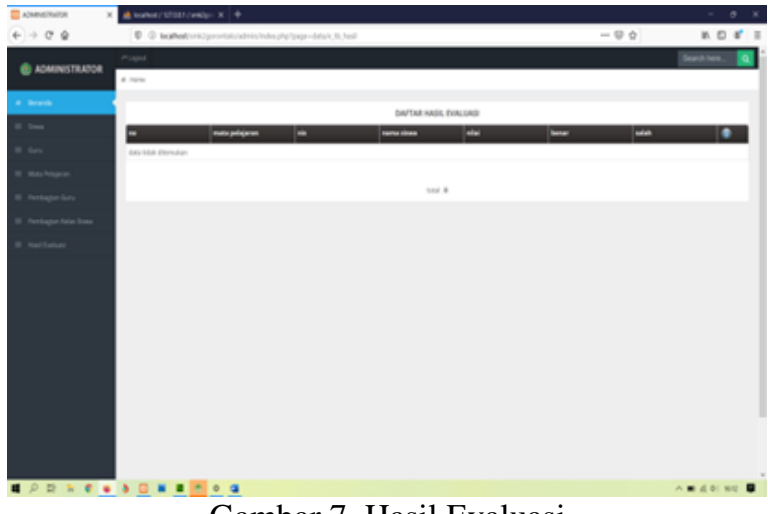

Gambar 7. Hasil Evaluasi

Tampilan gambar 7 adalah tampilan hasil evaluasi, evaluasi yang dimaksud dalam sistem ini adalah hasil kerja siswa yang telah menjawab tugas yang diberikan dan dikerjakan secara mobile.

7. Tampilan Hasil Ujian

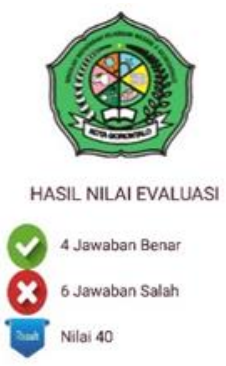

Gambar 8. Hasil ujian.

Tampilan Gambar 8 adalah tampilan hasil ujian yang diterima oleh siswa setelah mengisi tugas yang diberikan oleh guru. Siswa terlebih dahulu menginstal aplikasi mobile learning di Smartphone masing - masing dan masuk dalam sistem menggunakan Username dan password yang diberikan oleh admin. 
Pengujian sistem dilakukan untuk mengukur apakah sistem yang dikembangkan telah sesuai dan dapat berjalan dengan alur yang telah direncanakan sebelumnya. Dalam pengujian sistem penulis menggunakan metode, [16] yaitu:

Flowgraph dan Pseudocode

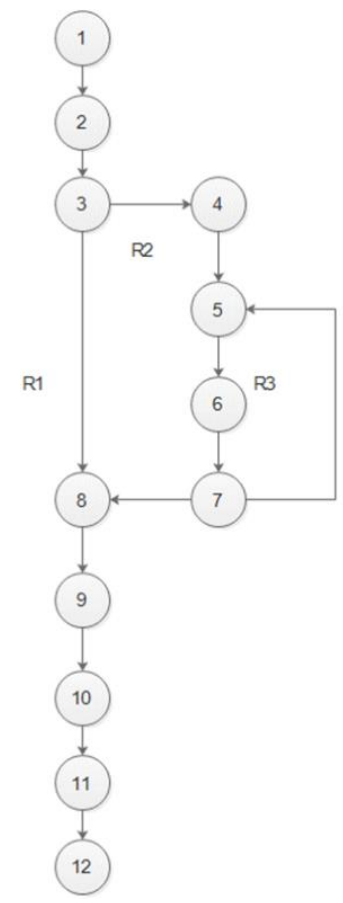

Gambar 9. Flowgraph

Pseudocode

Node 1 : Start / mulai

Node 2 : Login

Node 3 : Memilik Akun? Jika Tidak ke Node 4, Jika Ya Ke Node 8

Node 4 : Pilih Registrasi

Node 5 :InputBiodata umum

Node 6 : Simpan Data

Node 7 : NISN Terdaftar.? Jika Ya Ke Node 5, Jika Tidak Ke Node 8

Node 8 : Login Masukan NISN dan Password

Node 9 : Pilih menu biodata dna berkas

Node 10 : Lengkapi Biodata khusus dan Pilih Jurusan

Node 11: Simpan Data

Node 12 : Finish/ selesai

Perhitungan Cyclomatic Complexcity (CC)

Dari flowgraph untuk modul melengkapi data di atas di ketahui bahwa nilai:

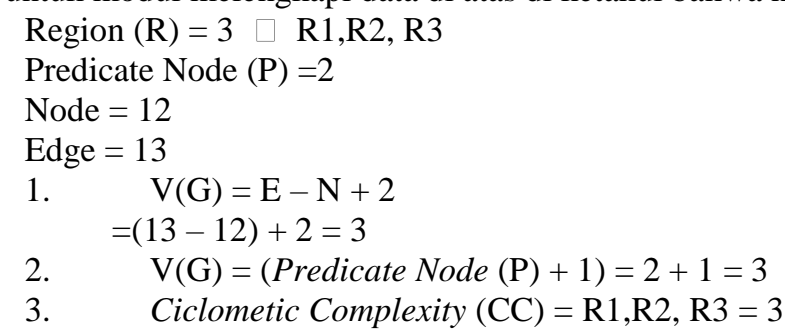

\section{Implementasi Sistem}

Sistem yang dirancang selanjutnya akan diimplementasikan pada SMK Negeri 2 Gorontalo. Untuk siswa dapat di akses di mana saja dan kapan saja dengan menggunakan Smartphone.

\section{KESIMPULAN}

Aplikasi dapat membantu siswa dalam melakukan aktifitas belajar, serta dapat membantu pihak guru dalam mengajar. Hal ini dapat dilihat pada hasil pengujian Whitebox pengujian sistem diperoleh hasil sesuai 
yang diharapkan maka dapat dinyatakan bahwa sistem ini dapat di implementasikan pada lokasi penelitian. Berikut hasil pengujian yang di ambil dari modul melengkapi biodata:
a. $\mathrm{V}(\mathrm{G})=13-12+2=3$
b. $\mathrm{V}(\mathrm{G})=2+1=3$
c. Cyclomatic Complexity (CC) $\mathrm{R} 1, \mathrm{R} 2, \mathrm{R} 3=3$

\section{UCAPAN TERIMA KASIH}

Ucapan syukur alhamdulillah pada Allah SWT dan terima kasih untuk Para Guru di SMK Negeri 2 yang telah bersedia meluangkan waktunya untuk melakukan wawancara ditengah situasi pandemi, Tidak lupa terima kasih juga untuk editor dan team JSAI yang telah membantu kami untuk mempublikasikan penelitian.

\section{REFERENCES}

[1] R. S. Indahini, Sulton, and A. Husna, "PENGEMBANGAN MULTIMEDIA moBiLE LEarNiNg PADA MATA PELAJARAN SIMULASI DAN KOMUNIKASI DIGITAL KELAS X SMK,” J. Kaji. Teknol. Pendidik., vol. 1, no. 2, pp. 141-148, 2018.

[2] A. dkk Kurniasari, "Analisis efektifitas pelaksanaan Belajar dari rumah selama pandemi covid 2019," J. Rev. Pendidik. Dasar J. Kaji. Pendidik. dan Has. Penelit., vol. 6, no. 3, pp. 1-8, 2020, [Online]. Available: http://journal.unesa.ac.id/index.php/PD.

[3] F. N. Arifa, "Tantangan pelaksanaan kebijakan belajar dari rumah dalam masa darurat covid-19," Info Singk. Kaji. Singk. terhadap Isu Aktual dan Strateg., vol. 7, no. 1, pp. 13-18, 2020.

[4] I. Aripin, "Konsep Dan Aplikasi Mobile Learning Dalam Pembelajaran Biologi," Angew. Chemie Int. Ed. 6(11), 951-952., vol. 3, no. April, pp. 1-9, 1967.

[5] E. Tan and H. J. So, "Rethinking the impact of activity design on a mobile learning trail: The missing dimension of the physical affordances," IEEE Trans. Learn. Technol., vol. 8, no. 1, pp. 98-110, 2015, doi: 10.1109/TLT.2014.2376951.

[6] J. Nouri and T. Cerratto-Pargman, "Characterizing Learning Mediated by Mobile Technologies: A Cultural-Historical Activity Theoretical Analysis," IEEE Trans. Learn. Technol., vol. 8, no. 4, pp. 357-366, 2015, doi: 10.1109/TLT.2015.2389217.

[7] Y. P. Rachma, D. Setyadi, and H. L. Mampauw, "Pengembangan Mobile Learning Barusikung Berbasis Android pada Materi Bangun Ruang Sisi Lengkung," Mosharafa J. Pendidik. Mat., vol. 9, no. 3, pp. 475-486, 2020.

[8] M. M. Elaish, N. A. Ghani, L. Shuib, and A. Al-Haiqi, "Development of a Mobile Game Application to Boost Students' Motivation in Learning English Vocabulary," IEEE Access, vol. 7, pp. 1332613337, 2019, doi: 10.1109/ACCESS.2019.2891504.

[9] E. Elfiona, M. Zaim, and Refnaldi, "Mobile-Based Media as the Solution in Teaching and Learning Listening Skill," J. Phys. Conf. Ser., vol. 1387, no. 1, 2019, doi: 10.1088/1742-6596/1387/1/012024.

[10] K. Alhumaid, M. Habes, and S. A. Salloum, "Examining the Factors Influencing the Mobile Learning Usage during COVID-19 Pandemic: An Integrated SEM-ANN Method," IEEE Access, vol. 9, pp. 102567-102578, 2021, doi: 10.1109/ACCESS.2021.3097753.

[11] Sugiyono, Metode Penelitian Kombinasi (Mixed Methods). Bandung: Alfabeta, 2014.

[12] S. Arikunto, Prosedur Penelitian Suatu Pendekatan Praktik. Jakarta: Rineka Cipta, 2010.

[13] Sugiono, Metode penelitian kuantitatif, kualitatif dan research and development. Bandung: Alfabeta, 2017.

[14] Priyono, Metode Penelitian Kuantitatif. Sidoardjo, 2016.

[15] A. Nugroho, Rekayasa perangkat lunak menggunakan UML dan JAVA. Yogyakarta: Andi Offset, 2010.

[16] R. Pressman, Rekayasa perangkat Lunak: Pendekatan praktisi (Buku Satu). Yogyakarta: Andi Offset, 2010. 